\title{
RESEARCH ARTICLE \\ Evaluation of nutritional compositions and haematological effect of locally produced fish feeds in Heterobranchus Bidorsalis (catfish) Fingerings
}

\author{
Haruna Ademu ${ }^{1 *}$, Adamu Yusuf Kabiru ${ }^{1}$, Abdulkadir Abubakar ${ }^{1}$, Enemali Ojochenemi \\ Johnpaul' ${ }^{1}$, and Khadeejah O. Nasir-Naeem²
}

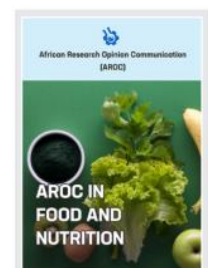

${ }^{1}$ Department of Biochemistry, School of Life Sciences, Federal University of Technology, Minna, Nigeria ${ }^{2}$ Biotechnology Advanced Research Centre, Sheda Science and Technology Complex, Nigeria

* Correspondence:

Haruna Ademu

Email: ademuharuna41@gmail.com

Received: 24 June 2021, Revised: 15 August 2021, Published: 27 September 2021

\section{ABSTRACT}

Background: The Insufficient feed availability in the natural or artificial environment of fish has resulted in their competition for survival. This has also brought about their poor yields and population depletion in their environment. Thus, supplementation of fish feed with cheap locally produced diets containing the essential nutrients needed for fish survival and growth is a necessity. In the present study, we evaluated the nutritional compositions and haematological effect of locally produced fish feed on Heterobranchus Bidorsalis (Catfish) fingerlings. Methods: Pearson's square method was used to formulate three diets A, B and C using different fractions of local ingredients. A commercial feed (Coppens) was used as a control diet. The feeds were evaluated for proximate, minerals, and amino acid compositions. Forty fingerlings of $2 \mathrm{~g}$ body weight were divided into 4 groups consisting of ten fingerlings each. Groups $A-C$ were fed the formulated diets while group $D$ was fed with the commercial feed. Each group was fed $5 \%$ of their average body weight twice daily in an aquarium for 49 days. Results: The results revealed a significant increase $(p<0.05)$ in protein $(44.12 \pm 0.15 \%)$, amino acids and minerals contents of diet $A$ than other formulated diets ( $B$ and $C$ ) but lower than the control diet. The results of haematological parameters showed that fingerlings fed formulated diet $A$ was significantly higher in values for RBC, haemoglobin and PCV but lower in WBC contents than the groups fed formulated diets $B$ and C. Conclusion: Formulated diet A yielded a better result in terms of protein content, and haematological status of the catfish. Therefore, formulated diet $A$ is the most preferably alternative for catfish fingerlings rearing Keywords: Heterobranchus Bidorsalis; Catfish Fingerlings; proximate; minerals; amino acid; hematological Citation: Ademu, H., Kabiru, A.Y., Abubakar, A., Johnpaul, E.O., and Nasir-Naeem, K.O. (2021). Evaluation of nutritional compositions, and haematological effect of locally produce fish feeds in Heterobranchus Bidorsalis (Catfish) fingerlings. AROC in Food and Nutrition, 1(2), 01-09, https://doi.org/10.53858/arocfn01020109

\subsection{Introduction}

Most living organisms rely on plants and animals as a source of nutrients for necessary substances needed by the body to play out its daily functions properly [1]. Nutrients including the carbohydrates, proteins, fats, and minerals are gotten through diet intake. These fundamental substances give energy, forms new body components, and assist in the metabolic activities of the body system [2].

Apart from milk and egg, no single food can adequately provide complete necessary nutrients for the growth, development and maintenance of life [3]. Researches have proven that the early stage of growth of some organisms such as mammals and fishes depend on milk and eggs for growth, development and maintenance of life [4].
However, on attaining a certain stage of development, milk and egg will no longer supply the adequate nutritional requirements for these organisms [2]. The first stage in the life of a fish is completed at the expense of the reserves which it receives from the egg yolk. The fish can only live on its yolk for a short period after which it goes on natural or supplementary feed completely [5].

Nigeria is the second-largest catfish producing country in African, and catfish contribute about $40 \%$ of the country's economy [6]. However, fish farming in Nigeria is faced with different challenges such as poor management practices, poor funding, government regulations, flooding, poor security, the problem of predators, the incidence of diseases and poor water quality [7]. In addition, fish farming is capital 
intensive and the high cost of commercial feed importation has contributed to its low production rate in Nigeria [8]. Since the use of conventional fish feed is not cost-effective, efforts are being directed globally towards discovering cheaper, readily available, and highly digestible alternative sources of feed for fish [9]. This will help to forestall the problem of feed nutrition. However, attempts at searching for these unconventional sources as supplements or total replacement is a difficult task [10].

Fish feed consists of natural feed and rations that are prepared artificially. Microscopic plants (phytoplankton), microscopic animals (zooplankton) such as insects, crustaceans, copepods, and molluscs [11]. Fish growth can be enhanced in their natural or artificial environment through fertilization. This is achieved by adding indispensable nutrients needed for their optimum growth into the water bodies locally. These indispensable nutrients are animal faeces immersed in the fish pond for about 5 days before introducing the fish into the pond $[11,12]$. They can live on natural feeds alone if the availability of natural feed present in their natural or artificial environment is sufficient for their survival. Though for large fish production, fish are stocked at a very high density and thus fertilizer applied to their natural or artificial environment may not be sufficient for optimum growth and maturity [13].

The insufficient availability of feed in the natural or artificial environment of fish has resulted in competition for survival. This has brought about poor yields and depletion in their population [14]. Thus, it is necessary to supplement their natural feed with artificially produced diets compounded from some locally available raw materials (of plants and animals' sources) which contain the essential nutrients needed by the fish for growth and maturity [15]. The aim of the present study is to produce different feed formulations from locally available ingredients and evaluate the feeds for nutritional compositions and their effect on haematological parameters of African catfish

\subsection{Materials and Methods}

\subsection{Sample Collection}

The samples utilized for this study were obtained from International Market, Minna in Niger State between the month of March and
April 2019. They are as follows: Fish waste, bone meal, Groundnut cake, Guinea corn, Cassava starch (Binders) and Vitamin premix. Bone meal used in this study was obtained from Sammy ventures Sabon Kasuwa Minna, Niger State. A total of 40 fingerlings catfish were bought from the Department of Fisheries, Ahmadu Bello University, Zaria.

\subsection{Specimen Identification}

Both the (red) guinea corn (Sorghum bicolor) and the groundnut cake samples were identified and authenticated by Dr. A. Saidu in the Department of Plant Biology, Ahmadu Bello University, Zaria. The fish waste and bone meal samples were also identified and authenticated by Prof. S. O. Abubakar in the Department of Zoology, ABU, Zaria.

\subsection{Samples Preparation}

The Fish waste, groundnut cake and guinea corn collected were grinded separately into powder and preserved in plastic bottles for further analysis

\subsection{Diet Formulation}

Three diets ( $A, B$ and $C$ ) were formulated by Pearson's square method as described by Wagner \& Stanton [16]. Fish waste, guinea corn, groundnut cake, bone meal, binders (cassava starch), water and vitamin premix were used for the formulation. The diets were formulated to have the same crude protein of $45 \%$ as the commercial feed (coppens). In the formulation, bone meal and vitamin premix were added as sources of minerals and vitamins. Cassava starch was added to enhance the proper agglutination of the feed. The diets were pelleted using the pelleting machine with a blade size of $1 \mathrm{~mm}$ [17].

\subsection{Analysis of minerals composition}

The concentration of sodium, potassium, calcium, magnesium, copper, manganese, iron zinc and phosphorus in commercial feed and the formulated diets $(A, B$, and $C)$ were analysed according to the standard protocol of AOAC [18]. Ten $(10 \mathrm{~g})$ grams of each of the samples was heated over a flame and ashed in a muffle furnace at $450^{\circ} \mathrm{C}$ for $8 \mathrm{hr}$. Ten (10 $\mathrm{cm}^{3}$ ) of diluted $\mathrm{HCl}$ was added to the ash and boiled for 5 minutes. The boiled ash was made up to $100 \mathrm{~cm}^{3}$ with distilled water. Analysis was performed in triplicate using atomic absorption spectrophotometer according to the standard methods of AOAC [18]. 


\subsection{Analysis of Proximate composition}

The proximate compositions including; crude proteins, crude fibre, moisture content, ash content, crude fat and carbohydrate contents of commercial feed and the formulated diets $(A, B$, and $C)$ were determined using standard procedures [18].

\subsection{Analysis of the amino acids (AA) compositions}

The amino acid compositions of commercial feed and the formulated diets (A, B, and C) were analyzed according to the protocol described in a previous study [19]. Briefly, ten $(10 \mu \mathrm{L})$ of defatted samples were analyzed for the amino acid profile using Amino Acid Analyser (TSM), (Technicon Instruments Corporation, New York). The analysis period was 76 min with a column flow rate of 0.50 and reproducibility consistent within $\pm 3 \%$. The net height of each peak produced by the chart record of TSM was measured and calculated for the amino acid it represented.

\subsection{Feeding Trial}

A total of 40 fingerlings catfish (2-3 g) were bought from the Department of Fisheries, $A B U$, Zaria. The fingerlings were kept under experimental standard laboratory conditions of $23.2-34.0^{\circ} \mathrm{C}[20]$. The animals were divided into 4 groups consisting of 10 fingerlings each. The first group was fed commercial feed (coppens), while the remaining groups were fed with the respective experimental diets; A, B, and C. Each group was fed $5 \%$ of their average body weight twice daily in an aquarium for 49 days.

\subsection{Haematological analysis}

At the end of the experiment, the blood sample was collected according to the method of MUAWC, [21]. The blood sample was collected in an EDTA sample bottle. The haematological components including packed cell volume (PCV), haemoglobin (HGB), red blood cells (RBC) and white blood cells (WBC) were analysed using automated haematological analyzer SYSMEX KX-21 as described by Dacie and Lewis [22].

\subsection{Statistical Analysis}

Data were analyzed using Statistical Analysis System (SAS) and presented as means \pm SEM. Comparisons between different groups were carried out by one-way analysis of variance (ANOVA) followed by Duncan's Multiple Range Test (DMRT). The level of significance was set at $\mathrm{P}<0.05$

\subsection{Results}

\subsection{Proximate composition of commercial feed (coppens) and formulated diets.}

There was a significant difference $(p<0.05)$ between the moisture content of the feed. Among all the formulated diets, diet A $(2.97 \pm 0.27 \%)$ had the lowest moisture content but higher than the commercial feed. The lipid content of diet A $(11.67 \pm 0.17 \%)$ was significantly higher than in diets $B$ and $C$ but lower than the commercial feed. Protein content was found to be significantly higher in formulated diet $A(44.12 \pm 0.15 \%)$ than other formulated diets ( $B$ and $C$ ) but lower than the commercial feed $(44.83 \pm 0.17 \%)$. The crude fibre in all the formulated diets was found to be significantly higher in formulated diet $A$ $(13.02 \pm 0.07 \%)$ than other formulated diets ( $B$ and $C$ ) and there was no significant difference $(p>0.05)$ with the commercial feed $(13.07 \pm 1.07 \%)$. The same trend was observed for ash content. Among all the formulated diets, the carbohydrate composition of the formulated diet $\mathrm{C}$ $(26.33 \pm 0.17 \%)$ was found to be significantly higher $(p<0.05)$ than other formulated diets (A and B). However, commercial feed $(20.20 \pm 0.21 \%)$ had the lowest carbohydrate content (Table 1 ).

Table 1: Proximate composition of commercial feed (coppens) and formulated diets.

\begin{tabular}{|ccccc|}
\hline composition (\%) & Feed Coppens & Diet A & Diet B & Diet C \\
\hline Moisture & $2.17 \pm 0.07^{\mathrm{a}}$ & $2.97 \pm 0.27^{\mathrm{b}}$ & $4.97 \pm 0.19^{\mathrm{c}}$ & $6.07 \pm 0.26^{\mathrm{d}}$ \\
\hline Lipids & $12.17 \pm 0.07^{\mathrm{d}}$ & $11.67 \pm 0.17^{\mathrm{c}}$ & $11.10 \pm 0.06^{\mathrm{b}}$ & $10.03 \pm 0.12^{\mathrm{a}}$ \\
\hline Protein & $44.83 \pm 0.17^{\mathrm{c}}$ & $44.12 \pm 0.15^{\mathrm{b}}$ & $42.47 \pm 1.63^{\mathrm{a}}$ & $41.17 \pm 0.17^{\mathrm{a}}$ \\
\hline Crude fibre & $13.07 \pm 1.07^{\mathrm{c}}$ & $13.02 \pm 0.07^{\mathrm{c}}$ & $12.60 \pm 0.20^{\mathrm{b}}$ & $12.07 \pm 0.37^{\mathrm{a}}$ \\
\hline Ash & $4.47 \pm 0.94^{\mathrm{b}}$ & $4.43 \pm 1.45^{\mathrm{b}}$ & $4.03 \pm 1.07^{\mathrm{a}}$ & $4.04 \pm 0.47^{\mathrm{a}}$ \\
\hline Carbohydrate & $22.20 \pm 0.21^{\mathrm{a}}$ & $23.57 \pm 0.17^{\mathrm{b}}$ & $24.83 \pm 0.29^{\mathrm{c}}$ & $26.33 \pm 0.17^{\mathrm{d}}$ \\
\hline
\end{tabular}

Values are means ( \pm Standard error of mean) of triplicate determinations. Values with different superscript in a row are significantly different from each other $(p<0.05)$. Key: Diet A: Fish Wastes + guinea corn + Additives, Diet B: Groundnut cake + Guinea corn + Additives Diet C: Fish wastes + Groundnut cake + Guinea corn + Additives 


\subsection{Total essential amino acid composition of the commercial feed and formulated diets}

The total essential amino acid in the commercial feed and the formulated diets is presented in table 2. Among all the formulated diets, diet A $(32.12 \pm 0.31 \mathrm{~g} / 100 \mathrm{~g}$ diet) was significantly higher $(p<0.05)$ in total essential amino acid composition than other formulated diets ( $B$ and $C$ ) but lower than the commercial feed $(35.67 \pm 0.37 \mathrm{~g} / 100$ $\mathrm{g}$ diet). However, in some amino acids such as arginine, histidine, leucine and phenylalanine there was no significant difference $(p>0.05$ ) in their levels between the formulated diet $A$ and the commercial feed.

\subsection{Non-essential amino acid composition of the commercial feed and formulated diets}

The non-essential amino acid composition in the commercial feed and formulated diets are shown in table 3 . The formulated diet $A$ $(37.67 \pm 0.54 \mathrm{~g} / 100 \mathrm{~g}$ diet) was significantly higher $(p<0.05)$ in total non-essential amino acid composition than other formulated diets ( $B$ and $C$ ) but lower than the commercial feed $(38.58 \pm 0.24 \mathrm{~g} / 100 \mathrm{~g}$ diet $)$. The values of some amino acids such as proline, alanine, glutamic acid, aspartic acid, serine, glycine and tyrosine revealed no significant difference $(p>0.05)$ in their levels between the formulated diet $A$ and the commercial feed.

Table 2: Total essential amino acid composition of commercial feed and formulated diets

\begin{tabular}{|c|c|c|c|c|}
\hline Amino acids (g/100 g diet) & Feed Coppens & Diet A & Diet B & Diet C \\
\hline Methionine & $1.32 \pm 0.04^{\mathrm{d}}$ & $0.50 \pm 0.01^{c}$ & $0.23 \pm 0.03^{b}$ & $0.20 \pm 0.05^{a}$ \\
\hline Arginine & $5.15 \pm 0.01^{c}$ & $5.14 \pm 0.04^{c}$ & $5.06 \pm 0.02^{b}$ & $4.67 \pm 0.03^{a}$ \\
\hline Threonine & $2.29 \pm 0.01^{d}$ & $2.15 \pm 0.02^{c}$ & $2.56 \pm 0.06^{b}$ & $2.22 \pm 0.02^{a}$ \\
\hline Tryptophan & $0.95 \pm 0.08^{d}$ & $0.91 \pm 0.01^{c}$ & $0.85 \pm 0.06^{b}$ & $0.62 \pm 0.02^{a}$ \\
\hline Histidine & $2.18 \pm 0.03^{b}$ & $2.14 \pm 0.01^{b}$ & $2.07 \pm 0.03^{b}$ & $1.77 \pm 0.12^{\mathrm{a}}$ \\
\hline Isoleucine & $3.61 \pm 0.06^{d}$ & $3.86 \pm 0.02^{c}$ & $3.44 \pm 0.04^{b}$ & $3.33 \pm 0.01^{a}$ \\
\hline Lysine & $4.44 \pm 0.03^{d}$ & $3.10 \pm 0.08^{c}$ & $1.01 \pm 0.03^{b}$ & $2.03 \pm 0.02^{\mathrm{a}}$ \\
\hline Leucine & $7.20 \pm 0.04^{c}$ & $7.10 \pm 0.05^{c}$ & $6.91 \pm 0.03^{b}$ & $5.25 \pm 0.08^{a}$ \\
\hline Valine & $4.28 \pm 0.05^{d}$ & $3.00 \pm 0.03^{c}$ & $2.96 \pm 0.01^{b}$ & $2.07 \pm 0.03^{a}$ \\
\hline Phenylalanine & $4.25 \pm 0.03^{b}$ & $4.22 \pm 0.04^{b}$ & $3.87 \pm 0.02^{a}$ & $3.79 \pm 0.02^{\mathrm{a}}$ \\
\hline$\Sigma$-Total essential amino acid & $35.67 \pm 0.37^{d}$ & $32.12 \pm 0.31^{\mathrm{c}}$ & $28.96 \pm 0.33^{b}$ & $25.95 \pm 0.35^{a}$ \\
\hline
\end{tabular}

Values differing in a row of different subscripts are substantially different $(p<0.05)$. Values of the formulated diets were obtained in $\mathrm{g} / 100 \mathrm{~g}$ proteins and converted to g/100 g. Key: Diet A: Fish Wastes + guinea corn + Additives, Diet B: Groundnut cake + Guinea corn + Additives Diet C: Fish wastes + Groundnut cake + Guinea corn + Additives

Table 3: Total non-essential amino acid composition of the commercial feed and formulated diets

\begin{tabular}{|l|l|l|l|l|}
\hline Amino acids (g/100 g diet) & Feed Coppens & Diet A & Diet B & Diet C \\
\hline Proline & $3.25 \pm 0.01^{c}$ & $3.23 \pm 0.03^{c}$ & $3.12 \pm 0.07^{\mathrm{b}}$ & $2.41 \pm 0.05^{\mathrm{a}}$ \\
\hline Cysteine & $1.16 \pm 0.04^{\mathrm{d}}$ & $0.29 \pm 0.02^{\mathrm{c}}$ & $0.21 \pm 0.02^{\mathrm{b}}$ & $0.19 \pm 0.04^{\mathrm{a}}$ \\
\hline Alanine & $4.30 \pm 0.02^{\mathrm{c}}$ & $4.28 \pm 0.01^{\mathrm{c}}$ & $4.07 \pm 0.04^{\mathrm{b}}$ & $3.85 \pm 0.03^{\mathrm{a}}$ \\
\hline Glutamic acid & $11.33 \pm 0.04^{\mathrm{c}}$ & $11.28 \pm 0.07^{\mathrm{c}}$ & $10.65 \pm 0.11^{\mathrm{b}}$ & $8.83 \pm 0.07^{\mathrm{a}}$ \\
\hline Aspartic acid & $8.86 \pm 0.03^{\mathrm{c}}$ & $8.83 \pm 0.04^{\mathrm{c}}$ & $7.46 \pm 0.01^{\mathrm{b}}$ & $6.47 \pm 0.03^{\mathrm{a}}$ \\
\hline Serine & $3.39 \pm 0.04^{\mathrm{c}}$ & $3.48 \pm 0.11^{\mathrm{c}}$ & $3.13 \pm 0.07^{\mathrm{b}}$ & $2.78 \pm 0.02^{\mathrm{a}}$ \\
\hline Glycine & $3.03 \pm 0.01^{\mathrm{c}}$ & $3.05 \pm 0.05^{\mathrm{c}}$ & $2.92 \pm 0.04^{\mathrm{b}}$ & $2.52 \pm 0.12^{\mathrm{a}}$ \\
\hline Tyrosine & $3.26 \pm 0.05^{\mathrm{c}}$ & $3.23 \pm 0.21^{\mathrm{c}}$ & $2.95 \pm 0.03^{\mathrm{b}}$ & $2.39 \pm 0.01^{\mathrm{a}}$ \\
\hline S-Total non-essential AA & $38.58 \pm 0.24^{\mathrm{d}}$ & $37.67 \pm 0.54^{\mathrm{c}}$ & $34.51 \pm 0.36^{\mathrm{b}}$ & $32.22 \pm 0.39^{\mathrm{a}}$ \\
\hline
\end{tabular}

Values differing in a row of different subscripts are substantially different $(p<0.05)$. Values of the formulated diets were obtained in $\mathrm{g} / 100 \mathrm{~g}$ proteins and converted to g/100 g diet. Key: Diet A: Fish Wastes + guinea corn + Additives, Diet B: Groundnut cake + Guinea corn + Additives Diet C: Fish wastes + Groundnut cake + Guinea corn + Additives

\subsection{Mineral composition of commercial feed and formulated diets}

The mineral composition of the commercial feed and formulated diets are shown in table 4. The mineral analysis results revealed a significant higher $(p<0.05)$ values of calcium
(138.85 $\pm 0.17 \mathrm{mg} / \mathrm{kg})$, copper $(0.28 \pm 0.01$ $\mathrm{mg} / \mathrm{kg})$, phosphorus (42.28 $\pm 0.02 \mathrm{mg} / \mathrm{kg})$, potassium $(230.33 \pm 0.33 \mathrm{mg} / \mathrm{kg})$, iron $(9.84 \pm 0.24 \mathrm{mg} / \mathrm{kg})$ and magnesium $(80.49 \pm 0.04 \mathrm{mg} / \mathrm{kg})$ in formulated diet $A$ than other formulated diets ( $B$ and $C$ ) but lower than the commercial feed. 


\subsection{Effects of formulated diets on hematological parameters of catfish.}

The effect of commercial feed and formulated diets on some haematological parameters are shown in table 5. The red blood cell, haemoglobin and packed cell volume for the group of fingerlings fed formulated diet A was higher in values compared to the groups of fingerlings fed formulated diets ( $B$ and $C$ ) but lower in values than the groups of fingerlings fed the commercial feed. The values of white blood obtained in fingerlings fed formulated diet A $\left(1.28 \pm 0.25 \times 10^{9} / \mathrm{L}\right)$ was lower in values than the groups of fingerlings fed formulated diets ( $B$ and $C$ ) but higher than the group of fingerlings fed the commercial feed $\left(0.73 \pm 0.33 \times 10^{9} / \mathrm{L}\right)$.

Table 4: Mineral composition of commercial feed and formulated diets

\begin{tabular}{|c|l|l|l|l|}
\hline Minerals (mg/kg) & Feed Coppens & Diet A & Diet B & Diet C \\
\hline Calcium (Ca) & $150.03 \pm 0.01^{\mathrm{d}}$ & $138.85 \pm 0.17^{c}$ & $130.49 \pm 0.03^{\mathrm{b}}$ & $120.62 \pm 0.01^{\mathrm{a}}$ \\
\hline Copper (Cu) & $1.28 \pm 0.02^{\mathrm{d}}$ & $0.28 \pm 0.01^{\mathrm{c}}$ & $0.07 \pm 0.02^{\mathrm{b}}$ & $0.02 \pm 0.03^{\mathrm{a}}$ \\
\hline Phosphorus (P) & $60.23 \pm 0.02^{\mathrm{d}}$ & $42.28 \pm 0.02^{\mathrm{c}}$ & $39.35 \pm 0.03^{\mathrm{b}}$ & $30.21 \pm 0.01^{\mathrm{a}}$ \\
\hline Potassium (K) & $250.04 \pm 0.03^{\mathrm{d}}$ & $230.33 \pm 0.33^{\mathrm{c}}$ & $211.23 \pm 0.07^{\mathrm{b}}$ & $121.29 \pm 0.20^{\mathrm{a}}$ \\
\hline Iron (Fe) & $12.83 \pm 0.07^{\mathrm{d}}$ & $9.84 \pm 0.24^{\mathrm{c}}$ & $5.85 \pm 0.08^{\mathrm{b}}$ & $3.61 \pm 0.02^{\mathrm{a}}$ \\
\hline Magnesium (Mg) & $91.27 \pm 0.06^{\mathrm{d}}$ & $80.49 \pm 0.04^{\mathrm{c}}$ & $78.39 \pm 0.03^{\mathrm{b}}$ & $60.58 \pm 0.02^{\mathrm{a}}$ \\
\hline
\end{tabular}

Values were obtained as a result of triplicate determination (means \pm Standard error of mean). Values differing in a row of different subscripts are substantially different $(p<0.05)$. Key: Diet A: Fish Wastes + guinea corn + Additives, Diet B: Groundnut cake + Guinea corn + Additives Diet C: Fish wastes + Groundnut cake + Guinea corn + Additives

Table 5: Effects of commercial feed and formulated diets on some hematological parameters of catfish.

\begin{tabular}{|lllll|}
\hline RBC (x 109/L) & Feed Coppens & Diet A & Diet B & Diet C \\
\hline HGB $(\mathrm{g} / \mathrm{dl})$ & $8.59 \pm 0.37^{\mathrm{d}}$ & $3.40 \pm 0.23^{\mathrm{c}}$ & $2.17 \pm 0.43^{\mathrm{b}}$ & $1.29 \pm 0.45^{\mathrm{a}}$ \\
\hline WBC $\left(\times 10^{\mathrm{d}} / \mathrm{L}\right)$ & $0.73 \pm 0.33^{\mathrm{a}}$ & $8.00 \pm 0.19^{\mathrm{c}}$ & $7.23 \pm 0.23^{\mathrm{b}}$ & $5.26 \pm 0.27^{\mathrm{a}}$ \\
\hline PCV $(\%)$ & $25.67 \pm 0.24^{\mathrm{d}}$ & $24.45 \pm 0.26^{\mathrm{c}}$ & $21.65 \pm 0.14^{\mathrm{b}}$ & $15.67 \pm 0.25^{\mathrm{a}}$ \\
\hline
\end{tabular}

Values were obtained as a result of triplicate determination (means \pm Standard error of mean). Values differing in a row of different subscripts are substantially different $(p<0.05)$. Key: Diet A: Fish Wastes + guinea corn + Additives, Diet B: Groundnut cake + Guinea corn + Additives Diet C: Fish wastes+ Groundnut cake + Guinea corn + Additives

\subsection{Discussion}

The carbohydrate content of the commercial feed and the formulated diets (table 1) suggests that the formulated diets are rich in energy and they are able to meet the $20 \%$ minimum amount of carbohydrate requirement for catfish feed supplementation as reported by Menghe et al. [23]. The higher carbohydrate content of formulated diet $\mathrm{C}$ may be attributed to the ingredients used for the formulation.

The protein content of the formulated diets obtained in this work is not in agreement with what was obtained by Musiba, et al. [24]. The significant higher protein content of the formulated diet $A$ than other formulated diets ( $B$ and $C$ ) is most likely attributed to the high crude protein of fish waste used for the formulation. The lower protein content of formulated diets $B$ and $C$ may be due to the plant-based sources of protein used in the formulation of the diet. This is in line with the report by Robinson et al. [25] that the use of plants as a source of protein supplements in fish feed formulation may be deficient and low in some amino acids like lysine and methionine which are the major growth promoter in fish feed and may as well contain anti-nutritional factors that may not be destroyed in the processing of feed.

The significantly lower $(p<0.05)$ moisture content of the formulated $\operatorname{diet} A$ than other formulated diets ( $B$ and $C$ ) is most likely attributed to drying and the sources of the ingredients used for the formulation. The moisture content of the formulated $\operatorname{diet} A$ and $B$ are similar to the findings of Aisha and ElTinay [26] who reported the moisture value in the range of $4.3-5.1 \%$.

The significant higher value in the lipid content of formulated diet A may be due to the fish waste and bone meal used in the formulation. Fish is not only a source of protein but also serve as a unique source of essential nutrients such as omega 3 and 6 fatty acids. Bone meals also contain a lot of fats and the two of them used for the formulation of diet A may account 
for the rise in the lipid level of formulated diet $A$ compared to formulated diets ( $B$ and $C$ ).

The ash content of formulated diet $\mathrm{B}$ and $\mathrm{C}$ in figure 4.2 is low and the non-significant difference $(p>0.05)$ between the ash content of the formulated diet $B$ and $C$ is probably due to the low composition of minerals in the formulated diets. The high ash content of formulated diet A may be due to the ingredients used for the formulation. The fish waste and bone meal used for the formulation are good sources of mineral elements and this could contribute to the high mineral content of formulated diet $A$. The non-significant difference between the ash content of formulated diet A and the commercial feed is most likely attributed to similarity in their mineral compositions. The ash content of formulated diet $A$ is within the range reported by Otunola et al. [27]. This observation was the same for crude fiber.

The observed consistent higher trend in amino acid values in the formulated diet $A$ over the formulated diet $B$ and $C$ may be due to the high crude protein content of the fish waste used for the formulation in Table 2. This agrees with the findings of Lacy \& Rutqvist [28] that animal sources of protein used in fish feed formulation are better in enhancing the protein contents of feed than plant sources of protein. The formulated diet $A$ with the highest total essential and non-essential amino acids than the other formulated diets ( $B$ and $C$ ) may be the most suitable diet to supply the necessary amino acids required for catfish growth and maturity.

The significantly higher values of mineral composition of formulated diet A (table 4) may be due to higher mineral compositions of the selected ingredients used for the formulation of the diet. Fish waste is rich in calcium, phosphorus, iron, zinc, iodine and potassium. Bone meal is rich in calcium, phosphorus, iron, magnesium and zinc. All these minerals present in this selected ingredient may be responsible for the high mineral content of formulated diet $A$. The significantly lower values for the mineral compositions of formulated diets $\mathrm{B}$ and $\mathrm{C}$ may be attributed to the low mineral composition of the selected ingredient used for the formulation of the diet. The non-significant difference $(p>0.05)$ between the formulated diet $B$ and $C$ may be that they have similar mineral compositions. However, these findings are not in agreement with the report of Modupe et al. [29]

Haematological parameters are strong clinical markers of the animal's physiological, dietary and pathological status [30]. They are also important in checking feed toxicity. Changes in the haematological parameters depend on age, fish species, diseases and the cycle of sexual maturity $[31,32]$.

The higher values of the red blood cell (RBC), haemoglobin $(\mathrm{Hb})$, and packed cell volume (PCV) of the groups of fingerlings fed formulated diet A compare to the groups of fingerlings fed the formulated diets ( $B$ and $C$ ) is an indication that formulated diet $A$ did not have any cytotoxic effect on the fingerlings. The higher values of RBC, $\mathrm{Hb}$ and PCV may be due to the high presence of mineral elements such as iron and copper in the formulated diet A. The presence of iron could stimulate the production of red blood cells which will increase the level of RBC, $\mathrm{Hb}$ and PCV. Ekpo [13] reported a similar finding that diets formulated with animal sources of protein and minerals has no major adverse impact on the haematological indices of fish. The lower value of white blood cell (WBC) of the groups of fingerlings fed formulated diet A compare to the groups of fingerlings fed formulated diets ( $B$ and $C$ ) may be that formulated diet $A$ did not contain toxic substances which may trigger the production of WBC. WBC is known to be produced whenever foreign invaders or toxic substances enter the system of an organism [33].

The lower count for RBC, $\mathrm{Hb}$ and PCV observed in the groups of fingerlings fed formulated diet B and C (table 5) could be attributed to the decreased level of protein in the formulated diet $B$ and may lead to inadequate nutrient requirements as protein are contributing factors of haemoglobin synthesis. This might have reduced the production rate of red blood cells or rise its damage. The result of red blood cell count is not in agreement with the findings of Ayoola [34].

The lower haemoglobin concentration of the groups of fingerlings fed formulated diets (B and C) may be attributed to the deficiency of some minerals in the formulated diets. This outcome is similar to the results of Adewolu and Aro [35]. White blood cells are the defence cells of the fish body. The rise in white 
blood cells of the groups of fingerlings fed formulated diets ( $B$ and $C$ ) could be attributed to the presence of toxic substrate in the formulated diet that may trigger the production of white blood cells in the haematopoietic tissue of the kidney in order to destroy foreign substances. This result is in agreement with the findings of Abalaka [36]. The lower packed cell volume of the groups of fingerlings fed formulated diets ( $B$ and $C$ ) may be ascribed to the presence of anti-nutritional factors, for example, haemagglutinin in the formulated diets which affect blood formation and growth. Packed cell volume of the groups of fingerlings fed formulated diets ( $B$ and $C$ ) were lower than recommended range (22-38) $\%$ for fish as reported by Erondu et al. [37]

\subsection{Conclusion}

Conclusively, the formulated $\operatorname{diet}$ A showed a better result in terms of proximate composition, mineral contents, protein value and haematological parameters compared to other formulated diets ( $B$ and $C$ ) studied. Therefore, formulated diet $A$ is a preferable alternative feed for catfish fingerlings rearing.

Competing interests: The authors declare that they have no competing interests

Ethical approval: Not applicable

Acknowledgement: The authors would like to appreciate the technical staff of the Department of Biochemistry, Federal University of Technology, Minna, for their assistances.

Author's contributions: The work was conducted in collaboration of all authors. All authors read and approved the final version of the manuscript.

\section{Funding: None}

\section{References}

1. Sales, J. and Janssens, G.P., 2003. Nutrient requirements of ornamental fish. Aquatic Living Resources, 16(6), pp.533-540.

2. Igah, S. A. (2008). Target food sources for formulating complementary/Supplementary foods for catfish purposes - a review. Bayero Journal of Pure and Applied Science, 2, 1123.

3. Henriksen, C., Eggesbø, M., Halvorsen, R. and Botten, G., 2000. Nutrient intake among two- year-old children on cows' milk-restricted diets. Acta paediatrica, 89(3), pp.272-278.

4. Bunyavanich, S., Shen, N., Grishin, A., Wood, R., Burks, W., Dawson, P., Jones, S.M., Leung, D.Y., Sampson, H., Sicherer, S. and Clemente, J.C., 2016. Early-life gut microbiome composition and milk allergy resolution. Journal of Allergy and Clinical Immunology, 138(4), pp.1122-1130.

5. Jiri, M. O., Marie, B. \& Martina, B.A. (2014). Comprehensive look at the possibilities of locally ingredients as diet for fish feed in Europe - a review. Polish Journal of Food and Nutrition Science, 64(3), 147-157.

6. Grema, H.A., Geidam, Y.A. and Egwu, G.O., 2011. Fish production in Nigeria: An update. Nigerian Veterinary Journal, 32(3).

7. Mwangi, G. (2008). Feed formulations and Feeding Technology for Fishes. International Research Journal of Pharmacy, 4(3), 223084077.

8. Tsado, J. H., Adeniji, O. B., Ojo, M. A., Adebayo, C.O. \& Abdulazzeez, R. (2012). Perception of women knowledge on the nutritive value of fish in kaduna north local government area of kaduna state, Nigeria. Journal of Agriculture and Social Research, 12(1), 162-169.

9. Tsado, A.N., Okoli, N.R., Jiya, A.G., Gana, D., Zubairu, R., Alhassan, H.E., and Salihu, I. Z. (2021). Effect of Supplementing Fish Diet with Grasshopper Meal On Growth Parameters of African Catfish (Clarias gariepinus). AROC in Agriculture, 1 (1); 0105,https://doi.org/10.53858/arocagr010101 $\underline{05}$

10. Asche F., Roll K.H., Tveterås S., 2008. Future Trends in Aquaculture: Productivity Growth and Increased Production, in: Holmer, M., Black K., Duarte, C. M., Marbà, N., Karakassis, I., Aquaculture in the Ecosystem, Springer Netherlands. pp. 271- 292.

11. Sikiru, B. O., Omobolanle, N. M. \& Adegoke, O. O. (2009). Improving Clarias productivity towards achieving food security in Ijebu Ode, Ogun State, Nigeria: A socio-economic analysis. Advances in Biological Research, 3(12), 24-28.

12. Wurts, W. A. (2003). Guidelines for producing Food-Size Channel Catfish. World Aquaculture, 23(1), 70-72

13. Ekpo, K. E (2011). Nutritional and Biochemical Evaluation of claria gariepinus 
fed with formulated diets in Southern Nigeria. Archives of Applied Science Research, 3(5), $428-444$.

14. Jhingran, V. G. (2009). Introduction to Aquaculture. Nigerian Institute for Marine Research, 5(2), 82-89.

15. Agbebi, O. T., Otubusin, S. O. \& Ogunleye, F. O. (2009). Effect of different levels of substitution of fish meal with blood meal in pelleted feeds on catfish Clarias gariepinus culture in net cages. European Journal of Scientific Research, 31(1), 6-10

16. Wagner, J. \& Stanton, T. L. (2016). Formulating Rations with the Pearson Square. Journal of World Aquaculture, 32 (2), 41-48.

17. Julius, O. M., Kevin, F., Charles, N., Elizabeth, O. \& Josiah, A. (2014). Formulation and manufacture of practical feeds for Western Kenya. Journal of World aquaculture, 39 (4), 541-548.

18. AOAC, 2000 Official Methods of Analysis 17th Edn, Association of Official Analytical Chemists, Washington, DC

19. Alawode, A.R., Ndamitso, M.M., Iyaka, A.Y., and Anuonye, C.J., (2021). Effects of fermentation on the proximate, antinutrients, minerals, fatty acids, and amino acids profiles of jujube (Ziziphus mauritiana Lam) seeds. AROC in Food and Nutrition, $1(1)$, 31-40, https://doi.org/10.53858/arocfn01013140

20. Dewan, S., Wahab, M. A., Beveridge, M. C., Rahman, M. H. \& Sarker, B. H. (1991). Food selection, selectivity and dietary overlap among planktivorous Chinese and Indian major carp fry and fingerlings grown in extensively manage, rain fed ponds in Bangladesh. Aquaculture Fish. Manage, 22, 277-294.

21. MUAWC, 2008. Blood collection guidelines. Monash University Animal Welfare Committee(MUAWC). pp.1-10. http://www.monash.edu.au/researchoffice/a nimal/assets/resources/bloodc ollectionmarch2008.pdf Retrieved 03-052012.

22. Dacie, J. V. and Lewis, S. M. (2015). Practical haematology. Sixth edition. Churchill Livingston, Edinburgh, Melbourne and New York. 6: 24 - 36.

23. Menghe, H. L., Edwin, H. R. \& Bruce B. M. (2001). A Practical Guide to Nutrition, Feeds, and Feeding of Catfish686-3242 (Second Revision).

24. Musiba, M.J., Ngupula, G.W., Kashindye, B.B., Elison, M., Shoko, A.P., Ndikumana, J., Zziwa E. \& Katunzi, E. F. B. (2014).Performance of Locally Formulated Feeds for Rearing of African Catfish in Tanzania. African Crop Science Journal, 22, 979 - 986.

25. Robinson, E. H., Li, M. H. \& Manning, B. B. (2001). A practical guide to nutrition, feeds and Feeding of Catfish. Mississipi Agricultural and Forestry Experiment Station Bulletin No. 1113 (Second Revision), 1(1), 20 - 27.

26. Aisha, S. M. F., \& El-Tinay, A. H. (2004). Effect of genotype, malt pretreatment and cooking on in-vitro Protein digestibility and protein fractions of cereal. Journal of Food Chemistry, 84, 613-619.

27. Otunola, E. T., Sunny-Roberts, E. O., Adejuyitan, J. A, \& Famakinwa, A. O. (2012). Effects of Addition of partially defatted groundnut paste on some Properties of kokoro' (a popular Snack made from maize paste). Agriculture and Biology Journal of North America, 16, 51-75.

28. Lacy, P., \& Rutqvist, J. (2016). Waste to wealth: The circular economy advantage. Springer.

29. Modupe, O. D., Godwin, O. O., Funmilola, A. \& Bello-Olusoji, O. A. (2012). Determination of mineral trace element and proximate analysis of fish feed. Food global science books, 3(2), 11-24

30. Berinyuy, E.B., Lawal, B., Olalekan, A.A., Olalekan, I.A., Yusuf, A.A., Sakpe, S. and Ossai, P.C., 2015. Hematological status and organs/body-weight parameters in Wister rats during chronic administration of Cassia occidentalis. International Blood Research \& Reviews, pp.1-7.

31. Olafedehan, C.O., Obun, A. M., Yusuf, M. K., Adewumi, O. O., Olafedehan, A.O., Awofolaji A.O. \& Adeniji A. A. (2010). Effects of residual cyanide in processed cassava peal meals on haematological and biochemical indices of growing fingerlings. Proceedings of $35^{\text {th }}$ Annual Conference of Nigerian Society of Animal Production, 212.

32. NseAbasi, N. E., Williams, M. E., Akpabio, U., \& Offiong, E. E .A. (2014). Haematological parameters and factors affecting their values. Agricultural Science, 2(1), 37- 47. 
33. Lawal, B., Shittu, O.K., Abubakar, A.N., Haruna, G.M., Sani, S. and Ossai, P.C., 2015. Haematopoetic effect of methanol extract of Nigerian honey bee (Apis mellifera) propolis in mice. J Coast Life Med, 3(8), pp.648-651.

34. Ayoola, S. O. (2014). Haematological characteristics of Clarias gariepinus (Burchell, 1822) juveniles fed with poultry hatchery waste. Iranica Journal of Energy and Environment, 2(1), 18-23

35. Adewolu, M.A. \& Aro, O. O. (2009). Growth, feed utilization and haematology of Clarias gariepinus (Burchell, 1822) fingerlings fed diets containing different levels of vitamin C. American Journal of Applied Sciences, 6(9), 1675-1681.

36. Abalaka, S. E. (2013). Evaluation of haematology and biochemistry of Clarias gariepinus as biomarkers of environmental pollution in Tiga dam, Nigeria. Brazilian Archives of Biology and Technology, 56(3), 371-376.

37. Erondu, E. S., Nnubia, C. \& Nwadukwe, F. O. (2003). Haematological studies on four catfish species raised in freshwater ponds in Nigeria. Nigerian Journal of Applied Ichthyology, 9, 250-256.
Submit your article to AROC JOURNALS

-AROC in Pharmaceutical and Biotechnology

-AROC in Agriculture

-AROC in Food and Nutrition

-AROC in Natural Product Research

-BIOMED Natural and Applied Science

Visit: https://arocjournal.com/

Copyright (c) 2021 Ademu et al. This is an open access article distributed under the terms and conditions of the Creative Commons Attribution License (CC BY) which allowed unrestricted download, distribution and reused as long as the original authors are properly cited. 